\title{
Esse est percipi \& verum factum est
}

\section{Jan Koenderink}

Published online: 18 September 2015

(C) Psychonomic Society, Inc. 2014

\begin{abstract}
I go into the historical roots of the fundamental issues relating to the "interface theory of perception," concentrating on the sciences rather than on philosophy. The basic ideas have been around throughout historical time. In modern times-I concentrate on a period straddling 1900 - they became perhaps "respectable," although interest has dwindled in the recent, postWorld War II period. This has been due to an ill-conceived reliance on "physical reality" that has shaped the sciences and philosophy alike. An investigation of the historical development of these ideas serves to shed additional light on various topics treated in the target article (D.D.Hoffman, M.Singh and C.Prakash: The interface theory of perception (this issue)).
\end{abstract}

Keywords Visual awareness · Visual meaning

I am mainly in sympathy with the concepts discussed in the target article. I have often used the "interface paradigm" myself (Koenderink, 2011, 2013) in vain attempts to kick people out of their mainstream slumber. The rare reactions, however, have been negative (e.g., Tyler, 2014). I foresee some frictions in getting the ideas of the authors accepted!

Yet the basic notions are hardly revolutionary. They occur in philosophy - that is, proto-science - from the earliest days, and the authors cite numerous occasions. I will not further address philosophical notions here, except for the citations from George Berkeley (1710) and Giambattista Vico (1725) in

J. Koenderink

Department of Experimental Psychology, University of Leuven (KU

Leuven), Leuven, Belgium

J. Koenderink

University of Sassari, Sassari, Italy

J. Koenderink $(\bowtie)$

Utrecht University, Utrecht, The Netherlands

e-mail: KoenderinkJan@gmail.com my title. Rather, I will concentrate on the sciences. As the sciences became established as such, the "interface idea" kept surfacing. I concentrate on the period from roughly 1850 to 1950, when the sciences - including psychology - may be said to have become of age. The topics that I will address are naturally related to the key concept of reality, including the issue of phenomenology.

\section{Reality}

The English word "reality" might be translated into German as either Realität or Wirklichkeit. This German distinction reveals a basic dichotomy. One reality is your awareness here and now, whereas the other reality is sometimes referred to as the physical world. Awareness is not to be confused with consciousness, a notion of self, or reflective thought. It simply is. It is the ultimate subjective fact. Because it is not an objective - that is, public - fact, it is outside the reach of science. The study of awareness is phenomenology. In contradistinction, the physical world is fully objective, because it is a public, scientific object. As the authors describe, the physical world is frequently used as a touchstone to assay the "veridical" nature of perceptual awareness. The mainstream is fully, albeit silently, committed to a belief - indeed, I can only call it a belief -in the "all seeing eye" (Koenderink, 2014). For instance, one aspect of the notion of "interface" involves its nonveridicality. Notice the touchstone that is applied.

It took physics a century to realize Kant's (1787) "Copernican revolution" (mentioned in the preface to the 2 nd edition of his Kritik der reinen Vernunft). A convenient date for this advance is 1894, with Heinrich Hertz's (1894) ideas in Die Prinzipien der Mechanik in neuem Zusammenhange. Max Planck (1944) finished it off-for instance, when he held that the causality principle is neither true nor false, but an act of faith, or that mind is the matrix of all matter. "Physical 
objects" have become recognized as symbolic forms, and physical reality as constructed from these. Nobody "understands" physics, perhaps least of all physicists. Physical reality has become our model, an interface. Of all the sciences, physics has progressed most decidedly to the interface model of reality. Quantum theory is an example of part of our present interface. Indeed it is distinctly "present," because the interface was different a century ago, and will again be different a century from now. It is common in philosophy and the other sciences to rely on physics as providing "reality" sub specie aeternitatis. As a physicist myself, I never stop to be surprised at the naïveté of this.

If our thoughts deal with "physical objects," they deal with symbolic forms. In 1874, Franz Brentano famously wrote, in Psychology From an Empirical Standpoint:

Every mental phenomenon is characterized by . . . the intentional inexistence of an object, ... direction toward an object (which is not to be understood here as meaning a thing), or immanent objectivity. . . . This intentional inexistence is characteristic exclusively of mental phenomena. No physical phenomenon exhibits anything like it. (1874/1995, pp. 88-89)

Brentano was - among other things — describing a "user interface model" of perception. Brentano's pupil Alexius Meinong (1899) described the objects in the interface as "subsisting," as opposed to "existing." Such objects included the "golden mountain" and the "round square" (which is surely as round as it is square!). He observed that thought throughout operates with subsisting objects, and so does science. In physics, the electron's wave function is such a subsisting object. This understanding led Cassirer (19231929) to the notion of "symbolic forms," which became influential in psychology (Lakoff, 1987) and the theory of arts (Langer, 1942, 1953). I will comment on psychology later, but first I consider biology.

\section{From biology to experimental phenomenology}

A critical turn in biology came in 1920, with Jakob von Uexküll's Theoretische Biologie. He came up with the first "neural model" of the "interface." It is his "neuer Kreis," which decades later(!) became widely known as Holst and Mittelstaedt's (1950) "Reafferenz Prinzip." According to this theory, the basic sensorimotor loop develops an additional reverse thread (von Uexküll's "new loop"), which "short circuits" the environment by predicting the effect of the efference on the afference. Von Uexküll clearly sees the fundamental importance, and speaks of the "counter world" (Gegenwelt) or "mirror world" (Spiegelwelt). He sees it as an implementation of Kant's ideas: The animal experiences the counter world, while the (naïve) "physical world" remains a Ding an sich. What is of primary interest here is that von Uexküll's counter world yields a model of the genesis of symbolic forms.

Von Uexküll is the true originator of ethology, although the origin is usually associated with a Nobel Prize (1973) shared by three biologists of the next generation. The far-reaching implications for the theory of mind have been most clearly articulated by Konrad Lorenz (1973), and especially by Rupert Riedl (1987), whose notion of "hypothetical realism" (formalized by Vollmer, 1975) does away with the recurring problem with Berkeley's "solipsism." This is essentially interface theory presented in an evolutionary context, almost exactly the topic of the target article. For the ethologist, it is a truism that perceptions serve fitness - or rather "veridicality," if there is such a thing.

Von Uexküll (1909, 1920) considered all animals to be equally complete. An animal without eyes is not "blind" in the sense of lacking anything. To think so is an anthropocentrism, a necessary by-product of the belief in the "all seeing eye." Instead, one considers the sense world (Merkwelt) and the action world (Wirkwelt) of the animal, which together make up its Umwelt. The Umwelt constrains the structural complexity of the interface. Umwelts vary with the complexity of the space-time framework. An animal like the sea squirt even loses space during the course of its life cycle. A famous example is the female tick, which hardly has a spatial frame, and for which a decade may pass as a moment. The tick's interface element corresponding to "mammal" is the coincidence of the smell of butyric acid and the feeling of warmth. Poor as such an Umwelt may seem to us, the tick is a highly successful animal; it has been around much longer than we have. Ticks once fed on dinosaurs! Its interface could hardly be better fitted to its lifestyle. A moment's consideration reveals that the human Umwelt does not include all animal Umwelts, but rather overlaps with them to various degrees. Thus, we fail to attain the position of the "all seeing eye," and enjoy a limited reality, though we-like the tick-experience it as "complete."

There is a certain notion common to artificial intelligence (AI) and the theory of mind - namely, that reality "can be computed from" or is "caused by" the physical world. This delusion is due to the silent belief in the "all seeing eye." Only modern physics and ethology have (largely) managed to steer free from it. The delusion is in no way harmless. A good many Nobel Prize winners (no names given!) have left their field of professional expertise to join the quest of "explaining consciousness." The result has been a pathetic horror story. Yet few people have profited from their brave examples, for the ghost hunt for the "neural center of consciousness" is still going on.

The "computations" supposed to go on in the head are purportedly Bayesian optimal strategies. This involves the 
"all seeing eye," because one needs a prior probability density on the physical world, a notion that it is hard to make sense of, that I would indeed say is self-contradictory. If such computations can be said to go on at all (but see Riedl, 1987), they must apply to the animal's Merkwelt and Wirkwelt. The authors of the target article are quite right in stressing this point in their own way, although they seem to hold that the (useless) notion of a prior on the physical world is not invalid, as such.

The more interesting researchers in early AI generally adopted the constructivist stance of Vico (verum factum est). This stream flourished in the mid-20th century among protoAI people such as Heinz von Foerster (1911-2002), William Ross Ashby (1903-1972), Warren McCulloch (1898-1969), and Ernst von Glasersfeld (1917-2010). The radical constructivists of the 1950s and '60s were rather more sophisticated than the present mainstream. The cyberneticians and "general systems" folks pushed the idea that "perception is not fundamentally different from hallucination." Conant and Ashby (1970) came up with the theorem that "Every good regulator must be a model of that system," putting von Uexküll's "counter world" on a formal basis. Perception as a user interface was understood. Heinz von Foerster could consider cognition to be "the computation of a reality," taking consistency, intersubjectivity, convergence, and confirmation as the necessary criteria for the value (i.e., fitness) of a perception; note that "truth" is a meaningless concept for the constructivist, because "veridicality" is a nonissue. In comparison, modern AI has mainly converted to the "all seeing eye" belief, so their "hard problem" has indeed become a problem.

Constructivism has played only a minor role in psychology; one primarily thinks of the work of Jean Piaget (1954). Constructivism and symbolic forms come together in modern work that is much in the line of von Uexküll's proto-ethology - think of Elisabeth Spelke (2011) in psychology, and Giorgio Vallortigara (Vallortigara, Pagni, \& Sovrano, 2004) in biology.

All this necessarily avoids the hairy topic of phenomenology: What is it like to have some specific interface? Indeed, modern experimental psychology is still essentially behaviorist, and so is animal ethology. Von Uexküll (1909) described animal Umwelts, and said that their Innenwelts ("inner worlds") would necessarily remain closed books to us. However, he certainly speculated on the nature of the Innenwelt, and suggested that perceptual qualities must be due to "functional tones" acquired through experience. Here he went way beyond James Gibson (1979), who believed - as the authors of the target article mention - that affordances are essentially features of the physical world, a notion that I consider incomprehensible. Von Uexküll related how the affordance of a matchstick for a toad may change between "elongated edible item" and "elongated item to be avoided," according to its recent experiences (Koenderink, 2014). Thus, he made a start with what may be called the "experimental phenomenology" of animals.

The concept of "functional tone" is a heuristic device. Indeed, there can be no scientific notion of "quality," because awareness itself is beyond the sciences (Koenderink, 2014). All one can do is come up with some "psychophysical correspondence rule" as a heuristic. This is perhaps acceptable if the rule is not in conflict with any scientific fact and has genuine heuristic value. The only example that I consider acceptable comes from Erwin Schrödinger (1944), who proposed that awareness is related to the violation of an expectation. This immediately maps on von Uexküll's "new loops," where expectations from the Gegenwelt meet samples from the Merkwelt. The higher animal has to be described in terms of a dense nexus of interrelated new loops; thus, one envisions myriads of Schrödinger-type "sparks of enlightenment" at numerous levels. This yields a thought model of awareness that fits well with Jason Brown's (2002) account developed on the basis of psychiatric observations.

It is perhaps of some interest to remark that von Uexküll was not a Darwinist. In fact, Lorenz called him a vitalist and seems to have been a little ashamed of his teacher. Of course, "Darwinism" has gone through its own evolution. I maintain that von Uexküll had a holistic view of evolution, whereas Darwinism has tended to concentrate on the parts. He would say that the spider and the fly "sing a duet together," and saw the organic world as a symphony. The authors of the target article steer a middle road in considering the coevolution of species, including the competition for finite ecological resources. This has ultimately to do with the ontology of von Uexküll's "new loops." These cannot be located in the physical world, but subsist in theoretical ethology. This implies that the mind is neither "in the head" nor "in the world." Here is an evolutionary argument against the relevance of such notions as "the center of consciousness" or "the hard problem of AI."

From a phenomenological perspective, awareness is made up of qualities, meanings, and values (Koenderink, 2014). It is as with a painting in which every touch has been applied by the painter, and thus is intentional and meaningful. Nothing is "arbitrary" or "random," even in a Jackson Pollock (1912-56) painting. A painting is to a photograph as awareness is to a file of "pointer readings," which is Sir Arthur Eddington's (1928) famous characterization of the physical world. The qualities, meanings, and values are the properties of our interface elements. We are intimately familiar with them (they are "us"), but how can one possibly study them? As one says, "the eye cannot see itself." Small wonder, then, that psychology has simply chosen to ignore them. This allows it to be a science, but perhaps degrades it into "dry physiology." One requires a kind of "experimental phenomenology." The closest instance that comes to mind is the work on perceptual Gestalts from the early 20th century. 
Gestalts are evidently "interface elements," as is clear from the fact that one may-in reflective thought - experience immediate awareness as "nonveridical." Gestalts have a definite template character, as the target article describes. Although the Gestalt schools understood the importance of expression in its interplay with impression, these notions were discarded with the advent of behaviorism and its immediate heir, cognitive science. The original Gestalt ideas are currently limited to a minor thread of experimental phenomenology. Gestalts as "templates" perhaps remind one of the "mental models" of Philip Johnson-Laird (1983) and George Lakoff (1987). Indeed, these are very much in the tradition of Johann Gottfried Herder, and represent a view that fits well within the interface idea. At the end of the 18th century, Herder (1772) identified language as a symbolic form that to a large part determines human reality. Herder acknowledged that mind ultimately derives from sensations, but he stressed that awareness "knows" these impressions only in terms of their linguistic expression. Expression conquers reality, leading to Friedrich Nietzsche's (1901) “Wille zur Macht." Herder noticed that parts are meaningless out of context and stressed the inseparability of form and content. Form is expression, and feelings are internal to meanings. Herder was a proto-Gestalt psychologist, with his notion of the interface being language. To me, it is evident that language is indeed important, but not everything. I like to believe that my animal friends are-like me-aware, even though they lack language as a symbolic form.

\section{Conclusion}

Much as I am in sympathy with the ideas expressed in the target article, I consider them part of a minor tradition in Western intellectual history that has been around for centuries. To me, this understream indeed makes much more sense than the mainstream. Unfortunately, it has met with major obstructions in the 20th century; I reckon it is about time for a reappraisal. This may well reveal my central European roots, since modern - predominantly Anglophone - science is firmly committed to ignoring history.

In summary, I would say the message is that the following mainstream beliefs are harmful to the understanding:

- he world is fully structured a priori,

- science's task is to discover this structure, and

- perception is veridical to the extent that it represents that structure,

whereas actually

- your reality is your (and of your ancestors', society's, ...) construction, esse est percipi, and
- your mind serves biological fitness, not a quest for "objective truth," verum factum est.

Mind adapts to the circumstances. So does reality. So does truth.

This is what the "interface theory" is about. If you retain that from the target article, it has hit the bull's eye.

Author note This work was supported in part by the Methusalem program by the Flemish Government (METH/08/02), awarded to Johan Wagemans, and by a visiting scientist grant from the University of Sassari, Sardinia.

\section{References}

Berkeley, G. (1710). A treatise concerning the principles of human knowledge. Dublin, Ireland: Aaron Rhames, for Jeremy Pepyat. Bookseller in Skinner Row.

Brentano, F. (1995). In O. Kraus \& L. L. McAlister (Eds.), Psychology from an empirical standpoint. London, UK: Routledge. Original work published 1874 .

Brown, J. W. (2002). Self-embodying mind: Process, brain dynamics and the conscious present. Barrytown, NY: Barrytown/Station Hill Press.

Cassirer, E. (1923-1929). Philosophie der symbolischen Formen. Berlin, Germany: Bruno Cassirer.

Conant, R. C., \& Ashby, W. R. (1970). Every good regulator of a system must be a model of that system. International Journal of Systems Science, 1, 89-97.

Eddington, A. (1928). The nature of the physical world (1927 Gifford Lectures). London, UK: Macmillan.

Gibson, J. J. (1979). The ecological approach to visual perception. Boston, MA: Houghton Mifflin.

Herder, J. G. (1772). Abhandlung über den Ursprung der Sprache. Berlin, Germany: Voss.

Hertz, H. (1894). Die Prinzipien der Mechanik in neuem Zusammenhange. Leipzig, Germany: Johann Ambrosius Barth.

Johnson-Laird, P. N. (1983). Mental models: Toward a cognitive science of language, inference and consciousness. Cambridge, MA: Harvard University Press.

Kant, I. (1787). Kritik der reinen Vernunft (2nd ed.). Riga: Johann Friedrich Hartknoch.

Koenderink, J. (2011). Vision as a user interface. In B. E. Rogowitz \& T. N. Pappas (Eds.), Human Vision and Electronic Imaging XVI (Proceedings of SPIE, Vol. 7865), 786504. doi:10.1117/12.881671

Koenderink, J. J. (2013). World, environment, Umwelt, and innerworld: A biological perspective on visual awareness. In B. E. Rogowitz, T. N. Pappas, \& H. de Ridder (Eds.), Human Vision and Electronic Imaging XVIII (Proceedings of SPIE, Vol. 8651), 865103. doi:10. $1117 / 12.2011874$

Koenderink, J. (2014). The all seeing eye? Perception, 43, 1-6.

Koenderink, J. (2014). Q. . . Perception, 43(10), 1015-1017;. doi:10. $1068 / \mathrm{p} 4310 \mathrm{ed}$

Lakoff, G. (1987). Women, fire and dangerous things. Chicago, IL: University of Chicago Press.

Langer, S. (1942). Philosophy in a new key: A study in the symbolism of reason, rite, and art. Cambridge, MA: Harvard University Press.

Langer, S. K. (1953). Feeling and form. New York, NY: Charles Scribner's Sons.

Lorenz, K. (1973). Die Rückseite des Spiegels. Munich, Germany: Piper. 
Meinong, A. (1899). Über Gegenstände höherer Ordnung und deren Verhältniss zur inneren Wahrnehmung. Zeitschrift für die Psychologie und Physiologie der Sinnesorgane, 21, 187-272.

Nietzsche, F. (1901). Der Wille zur Macht. Leipzig, Germany: Elisabeth Förster-Nietzsche \& Peter Gast.

Piaget, J. (1954). The construction of reality in the child. New York, NY: Basic Books.

Planck, M. (1944). Das Wesen der Materie [Speech presented at Florence, Italy]. Archiv zur Geschichte der Max-PlanckGesellschaft, Abt. Va, Rep. 11 Planck, Nr. 1797.

Riedl, R. (1987). Begriff und Welt: Biologische Grundlagen des Erkennens und Begreifens. Berlin, Germany: Parey.

Schrödinger, E. (1944). What is life? Cambridge, UK: Cambridge University Press.

Spelke, E. S. (2011). Natural number and natural geometry. In S. Dehaene \& E. Brannon (Eds.), Space, time and number in the brain: Searching for the foundations of mathematical thought. Attention and performance XXIV (pp. 287-317). San Diego, CA: Elsevier Academic Press.

Tyler, C. (2014). Is the mind in the head? A belated response to Koenderink (1999). Perception, 43, 103-106.

Vallortigara, G., Pagni, P., \& Sovrano, V. A. (2004). Separate geometric and non-geometric modules for spatial reorientation: Evidence from a lopsided animal brain. Journal of Cognitive Neuroscience, 16, 390-400.

Vico, G. (1725). Principi di scienza nuova. Naples, Italy: Stamperia La Muziana.

Vollmer, G. (1975). Evolutionäre Erkenntnistheorie. Stuttgart, Germany: Hirzel.

von Holst, E., \& Mittelstaedt, H. (1950). Das Reafferenzprinzip. Naturwissenschaften, 37, 464-476.

von Uexküll, J. (1909). Umwelt und Innenwelt der Tiere. Berlin, Germany: Springer.

von Uexküll, J. (1920). Theoretische Biologie. Berlin, Germany: Springer. 